\title{
Relative Properties and Localizations of Synaptic Vesicle Protein Isoforms: The Case of the Synaptophysins
}

\author{
Else Marie Fykse, ${ }^{1}$ Koji Takei, ${ }^{2}$ Christiane Walch-Solimena, ${ }^{2,3}$ Martin Geppert, ${ }^{1}$ Reinhard Jahn, ${ }^{2.3}$ Pietro De \\ Camilli, ${ }^{2}$ and Thomas C. Südhof ${ }^{1}$ \\ ${ }^{1}$ Department of Molecular Genetics and Howard Hughes Medical Institute, Universily of Texas Southwestern Medical \\ School, Dallas, Texas 75235 and Departments of ${ }^{2}$ Cell Biology and ${ }^{3}$ Pharmacology, Howard Hughes Medical Institute, \\ Yale University School of Medicine, New Haven, Connecticut 06510
}

Synaptophysins are abundant synaptic vesicle proteins present in two forms: synaptophysin, also referred to as synaptophysin I (abbreviated syp I), and synaptoporin, also referred to as synaptophysin II (abbreviated syp II). In the present study, the properties and localizations of syp I and syp II were investigated to shed light on their relative functions. Our results reveal that syp II, similar to syp I, is an abundant, $\boldsymbol{N}$-glycosylated membrane protein that is part of a heteromultimeric complex in synaptic vesicle membranes. Cross-linking studies indicate that syp II is linked to a lowmolecular-weight protein in this complex as has been observed before for syp I. Furthermore, after transfection into CHO cells, syp II, similar to syp I, is targeted to the receptormediated endocytosis pathway. Immunocytochemistry of rat brain sections reveals that syp II expression is highly heterogeneous, with high concentrations of syp II only in selected neuronal populations, whereas syp I is more homogeneously expressed in most nerve terminals. In general, nerve terminals expressing syp II also express syp I. In addition to high levels of syp II observed in selected neurons, a rostrocaudal gradient of syp II expression was observed in the cerebellar cortex. Immunoelectron microscopy confirmed that syp II is localized to synaptic vesicles. Immunoprecipitations of synaptic vesicles from rat brain with antibodies to syp I demonstrated that syp II is colocalized with syp I on the same vesicles. However, after detergent solubilization, no coimmunoprecipitations of the two proteins were observed, suggesting that they are not complexed with each other although they are on the same vesicles. Together our results demonstrate that syp I and syp II have similar properties and are present on the same synaptic vesicles but do not coassemble. The presence of the two proteins in the same nerve terminal suggests that they have similar but nonidentical functions and that the relative abundance of the two proteins may contribute to the functional heterogeneity of nerve terminals.

[Key words: synaptic vesicles, neurotransmission, synapse, synaptophysin, cerebellum, receptor-mediated endocytosis]

\footnotetext{
Received Feb. 17, 1993; revised Apr. 26, 1993; accepted May 11, 1993.

We thank Ms. A. Hopkins, I. Leznicki, E. Borowicz, and R. Cofiell for excellent technical assistance. We are grateful to Dr. I. Trowbridge for transferrin receptor antibodies.

Correspondence should be addressed to T. C. Südhof, Room Y5.322, HHMI, UT Southwestern Medical School, 5323 Harry Hines Boulevard, Dallas, TX 75235. Copyright (c) 1993 Society for Neuroscience $0270-6474 / 93 / 134997-11 \$ 05.00 / 0$
}

Synaptic vesicles are specialized secretory organelles in nerve terminals that actively accumulate neurotransmitters. Upon nerve terminal excitation, synaptic vesicles undergo exocytosis in a $\mathrm{Ca}^{2+}$-dependent manner, thereby releasing neurotransmitters. As specialized small organelles, synaptic vesicles contain a limited complement of proteins, many of which have been characterized at the molecular level (reviewed in Südhof and Jahn, 1991). Most of the proteins of synaptic vesicles are abundant in brain and are specific for synaptic vesicles there, suggesting that synaptic vesicles represent a unique pathway that is distinct from other intracellular membrane trafficking pathways.

Synaptic vesicle proteins exist in multiple isoforms. Multiple isoforms were first demonstrated for synapsins, abundant phosphoproteins on synaptic vesicles. They were shown to consist of a family of four proteins derived from two genes by alternative splicing (Südhof et al., 1989). More recently, other synaptic vesicle proteins have been shown to be present in brain in homologous but distinct forms: for synaptophysins and synaptobrevins, there are at least two forms each (Elferink et al., 1989; Archer et al., 1990; Knaus et al., 1990; Bixby, 1992); for synaptotagmins, at least three forms (Geppert et al., 1991; Wendland et al., 1991); and for rab3's, there are also at least three forms (Matsui ct al., 1988; Zahraoui et al., 1989; Fischer von Mollard et al., 1990; Matteoli et al., 1991). In all cases investigated, the different forms of synaptic vesicle proteins were found to be differentially distributed in brain. However, only in the case of the synapsins was this differential distribution addressed at the protein level to determine if the different isoforms of synaptic vesicle proteins are biochemically similar, and if they are colocalized in the same nerve terminals (Südhof et al., 1989). The occurrence of multiple isoforms raises the general question of their functional relevance: are different isoforms functionally different, or do they represent an evolutionary epiphenomenon?

Synaptophysins are among the most abundant synaptic vesicle proteins. There are at least two synaptophysins in brain, synaptophysin I (syp I; Jahn et al., 1985; Wiedenmann et al., 1985) and synaptoporin/synaptophysin II (syp II; Knaus et al., 1990; Bixby, 1992). Syp I represents approximately $6 \%$ of the total synaptic vesicle protein (Jahn et al., 1985), and syp II is also very abundant (see below).

The properties of syp I have been extensively investigated. Syp I contains four transmembrane regions with cytoplasmic amino and carboxyl termini (Johnston et al., 1989a). It is $N$-glycosylated on its first intravesicular loop and contains two in- 
tramolecular disulfide bonds that are located between the cysteines within each of the two intravesicular loops (Johnston and Südhof, 1990). Syp I is part of a high-molecular-weight complex composed of a variable number of syp I subunits in addition to low-molecular-weight subunits (Johnston and Südhof, 1990). In transfected fibroblasts expressing syp I, the protein is directed to the receptor-mediated endocytosis pathway and colocalizes with transferrin receptors (Johnston et al., 1989b; Cameron et al., 1991; Linstedt and Kelly, 1991a), although others find that it may create synaptic vesicle-like structures upon transfection (Leube et al., 1989). Data using ${ }^{45} \mathrm{Ca}^{2+}$ blotting suggested that syp I may bind $\mathrm{Ca}^{2+}$ (Rehm et al., 1986) but these data could not be confirmed by equilibrium dialysis (Brose et al., 1992). Purified syp I incorporated into planar lipid bilayers was found to represent a cation channel, but the protein used for these experiments was of a non-native subunit composition (Thomas et al., 1988). Although the precise function of syp I is unknown, two major hypotheses are currently considered. The first is that synaptophysin may he a component of the synaptic vesicle fusion pore, and the second that it is involved in the biogenesis and stability of synaptic vesicles (reviewed in Südhof and Jahn, 1991).

Little is known of the properties of syp II. It also appears to be an evolutionarily highly conserved synaptic vesicle protein (Knaus et al., 1990; Bixby, 1992). The high degree of homology between syp I and syp II suggests that they have similar transmembrane organizations. In situ hybridization studies demonstrated a differential distribution of syp I and syp II mRNAs in rat brain (Marqueze-Pouey et al., 1991). However, it was not possible with that technique to determine the precise relative localizations of these mRNAs and their encoded proteins.

In the present study, we have tried to determine systematically the properties of syp II in comparison with those of syp I to shed light on possible functions of the expression of synaptic vesicle protein isoforms. Principally, two hypotheses can be formulated regarding the relationship between synaptic vesicle protein isoforms in general and syp I and syp II in particular: (1) multiple forms of a protein could serve as functionally equivalent alternatives that are used in distinct neuronal pathways; (2) multiple isoforms could be coexpressed in a combinatorial manner with different relative amounts in different cells. This would suggest that different isoforms have distinct functions that may confer onto nerve terminals different properties depending on the combinatorial pattern of expression observed. The two hypotheses give the presence of isoforms different functional implications, with the first hypothesis assigning them pathway-specific functions whereas the second hypothesis suggests complex combinatorial effects of expression patterns of multiple isoforms.

The following questions were addresscd in the present study. (1) Given the high degree of homology between syp I and syp II, do they have similar biochemical properties? Characteristics that are shared between the two proteins would presumably be functionally relevant and be related to their in vivo role. (2) What is the relative distribution of the two proteins in the cells of the CNS? (3) If syp I and syp II are found in the same neuron, are they colocalized on the same organelle? (4) Given the multimeric nature of syp I, are they part of the same complex?

Our results show that syp II is expressed in a restricted number of nerve terminals whereas syp I is widely distributed. In the distinct populations of nerve terminals containing syp II, it is present at high levels and colocalizes with syp I. The two syn- aptophysins are found on the same synaptic vesicles biochemically. However, although both proteins are part of similar highmolecular-weight complexes and share major biochemical characteristics, they do not cocomplex. These results suggest that the two synaptophysins have similar but distinct functions, with syp I being the more general protein and syp II having a very heterogeneous distribution, with high levels only in a restricted number of nerve terminals.

\section{Materials and Methods}

Antibodies, SDS-PAGE, immunoblotting, and deglycosylation studies. Antibodies against syp II were raised in rabbits against a synthetic peptide (sequence in single-letter amino acid code: CEFGQQPSGPTSFNNQI) coupled to keyhole limpet hemocyanin as described (Johnston et al., 1989a). The antibody was affinity purified on a column containing the peptide immobilized on cyanogen-bromide-activated Sepharose 4B. Antibodies to syp I used in this study were described previously (Johnston and Südhof, 1990). Antibody specificity was confirmed using peptide inhibition studies and using cell lines expressing either syp I or syp II (see Fig. 2). SDS-PAGE was carried out according to Laemmli (1970); immunoblotting was performed as described using peroxidase-labeled or alkaline phosphatase-labeled secondary antibodies and color development or enhanced chemiluminescence (Amersham) for detection. For the deglycosylation studies, solubilized synaptosomal proteins were incubated for $1 \mathrm{hr}$ at $37^{\circ} \mathrm{C}$ in the presence or absence of PNGase F (New England Biolabs). PNGase F is a cloned version of endoglycosidase $F$ and was used according to the manufacturer's recommendations. The incubations were stopped by adding sample buffer and analyzing the samples by SDS-PAGF, followed by immunoblotting.

cDNA cloning, vector constructions, transfections, and cell culture. cDNA clones encoding syp II were isolated from a rat brain cDNA library as described (Südhof et al., 1987) using an oligonucleotide from the published syp II sequence (Knaus et al., 1990; sequence, GGATATGCAAAGGCTATGTC). Sequences from three clones examined were identical to the published sequence. The full-length coding region of cDNA clone p552-3a containing nucleotides 434-1375 of the syp II sequence (Knaus et al., 1990) was cloned into an expression vector utilizing a cytomegalovirus promoter. $\mathrm{CHO}$ cells were cultured and stably transfected and cell lines expressing syp II were selected as described (Johnston et al., 1989b). For the brefeldin A treatments, the drug was added to cultures for $20 \mathrm{~min}$ at a concentration of $10 \mathrm{mg} /$ liter. Cells were rinsed with medium and immediately fixed as described (Cameron et al., 1991).

Immunoprecipitations of synaptic vesicles and of solubilized proteins. For immunoprccipitations of synaptic vesicles, rat brain was homogenized in $0.32 \mathrm{~m}$ sucrose, $5 \mathrm{~mm}$ HEPES- $\mathrm{NaOH}, \mathrm{pH} 7.5$. The homogenate was cleared of larger structures by low-speed centrifugation $(20 \mathrm{~min}$ at $12,000 \times g$ ). The supernatant of this centrifugation (protein concentration, $6.5 \mathrm{gm} / \mathrm{liter}$ ) was incubated for $30 \mathrm{~min}$ at $4^{\circ} \mathrm{C}$ under agitation with beads containing covalently bound monoclonal antibodies to syp I (Burger et al., 1989). Beads were then separated from the medium by centrifugation $(1 \mathrm{~min}$ at $9000 \times \mathrm{g})$ and washed three times in the homogenization buffer prior to analysis by SDS-PAGE and immunoblotting. For immunoprecipitations of solubilized proteins, synaptosomes were solubilized at $4^{\circ} \mathrm{C}$ for $30 \mathrm{~min}$ in $1 \%(\mathrm{v} / \mathrm{v})$ Triton $\mathrm{X}-100,0.25 \mathrm{M} \mathrm{NaCl}$, $10 \mathrm{~mm}$ HEPES-NaOH, pH 7.4, $2 \mathrm{mg}$ /liter pepstatin, and $0.2 \mathrm{~mm}$ phenylmethylsulfonyl fluoride at a total protein concentration of $2 \mathrm{gm} /$ liter and in a total volume of $2 \mathrm{ml}$ per sample. Solubilized proteins were recovered in the supernatant of a $10 \mathrm{~min}$ centrifugation at $300,000 \times$ $g$, and $40 \mu \mathrm{l}$ of syp I and syp II and control antibodies were added to each sample. All antibodies were polyclonal, with antibodies to clathrin light chains used as controls. After $60 \mathrm{~min}$ incubation at $4^{\circ} \mathrm{C}$ on a rotator, protein A-Sepharose CL-4B was added and the sample was incubated for $60 \mathrm{~min}$ more under the same conditions. Then the antibodies bound to protein A-Sepharose were pelleted by centrifugation (1 min at 13,000 $\times g$ ) and washed three times prior to analysis by SDS-PAGE and immunoblotting.

Chemical cross-linking and disulfide cross-linking. Crude synaptic vesicles (Johnston et al., 1989a) were incubated in $0.2 \mathrm{M}$ HEPES-NaOH,

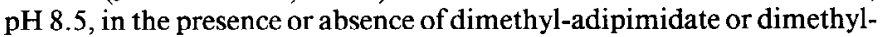
suberimidate (both from Pierce, Rockford, IL) at the indicated concentrations in a total volume of $0.2 \mathrm{ml}$ at a protein concentration of $1 \mathrm{gm} /$ 


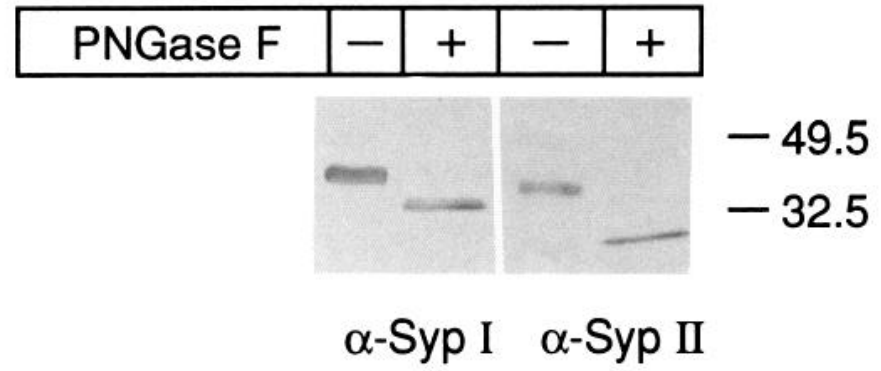

Figure 1. $\quad \mathrm{N}$-glycosylation of syp I and syp II as analyzed by endoglycosidase F cleavage. Synaptosomal proteins solubilized in Triton X-100 were incubated with PNGase F, a cloned form of endoglysidase $F$, or in control buffer, and then analyzed by SDS-PAGE (10\% gels, $20 \mu \mathrm{g}$ protein/lane) followed by immunoblotting using syp I and II antibodies and peroxidase-labeled secondary antibodies. Numbers on the right indicate positions of molecular weight markers.

liter for $3 \mathrm{hr}$ at room temperature under vigorous shaking. The reaction was stopped by the addition of $2 \mathrm{ml}$ of $0.2 \mathrm{M}$ HEPES-NaOH, $\mathrm{pH} 8.5$, and pelleting the vesicles by centrifugation $(15 \mathrm{~min}$ at $150,000 \times \mathrm{g})$. The pellets were resuspended in sample buffer and analyzed by SDSPAGE and immunoblotting. For the disulfide cross-linking, crude synaptic vesicles were reduced with $10 \% \beta$-mercaptoethanol and the reducing agent was removed by centrifugation to allow sulfhydryl group oxidation as described (Johnston and Südhof, 1990).

Immunocytochemistry. Double immunofluorescence of cultured cells and of frozen tissue sections was performed as described (Cameron et al., 1991; Takei et al., 1992). For immunogold labeling of brain homogenates and electron microscopy, cell fragments were embedded in agarose using the procedure described by De Camilli et al. (1983) with some modifications (Takei et al., 1992). Briefly, rat brain tissue was mildly homogenized in a loosely fitting glass-Teflon homogenizer in ice-cold $0.25 \mathrm{M}$ sucrose, $25 \mathrm{~mm} \mathrm{KCl}, 5 \mathrm{~mm} \mathrm{MgCl}{ }^{2}, 2$ mM EGTA, and $10 \mathrm{~mm}$ Na-phosphate buffer, $\mathrm{pH}$ 7.4. The homogenate was mixed with a large volume of ice-cold hypotonic fixative (3\% formaldehyde, $0.25 \%$ glutaraldehyde, and $5 \mathrm{~mm}$ Na-phosphate, $\mathrm{pH} 7.4$ ). Fixed cell fragments were pelleted by centrifugation, resuspended in $0.12 \mathrm{M} \mathrm{Na}$-phosphate buffer using a small glass-Teflon homogenizer, and embedded in agarose blocks. Immunogold labeling, postfixation, and plastic embedding of the agarose blocks were performed essentially as described (De Camilli et al., 1983; Takei et al., 1992).

\section{Results}

Using the published cDNA sequence as a guide (Knaus et al., 1990), full-length clones encoding syp II were isolated from a rat brain cDNA library. An expression vector for syp II was constructed in which syp II expression is driven by a cytomegalovirus promoter. In addition, an antibody was raised against a synthetic peptide derived from the carboxyl terminus of the amino acid sequence of syp II and affinity purified using immobilized peptide. Immunoblotting of rat brain membranes with the syp II antibody revealed a single immunoreactive band of approximately $M_{r} 37,000$ that migrated slightly faster on SDS-PAGE than syp I, suggesting that the antibody was specific for syp II (Fig. 1). Previous experiments have shown that syp I is $N$-glycosylated at a single site and that its carbohydrates can be removed by endoglycosidase F cleavage (Johnston et al., $1989 \mathrm{~b})$. We therefore tested if syp II is similarly $N$-glycosylated by digesting it with recombinant endoglycosidase $\mathrm{F}$ (Fig. 1). A major shift in the apparent molecular weight of syp II was observed, suggesting that it is also $N$-glycosilated. It is likely that the glycosilation of syp II is at the same site as that of syp I because the sequence of the $N$-glycosylation site is conserved between the two proteins (Knaus et al., 1990).

One of the most interesting properties of syp $I$ is that it is targeted to the receptor-mediated endocytosis pathway after

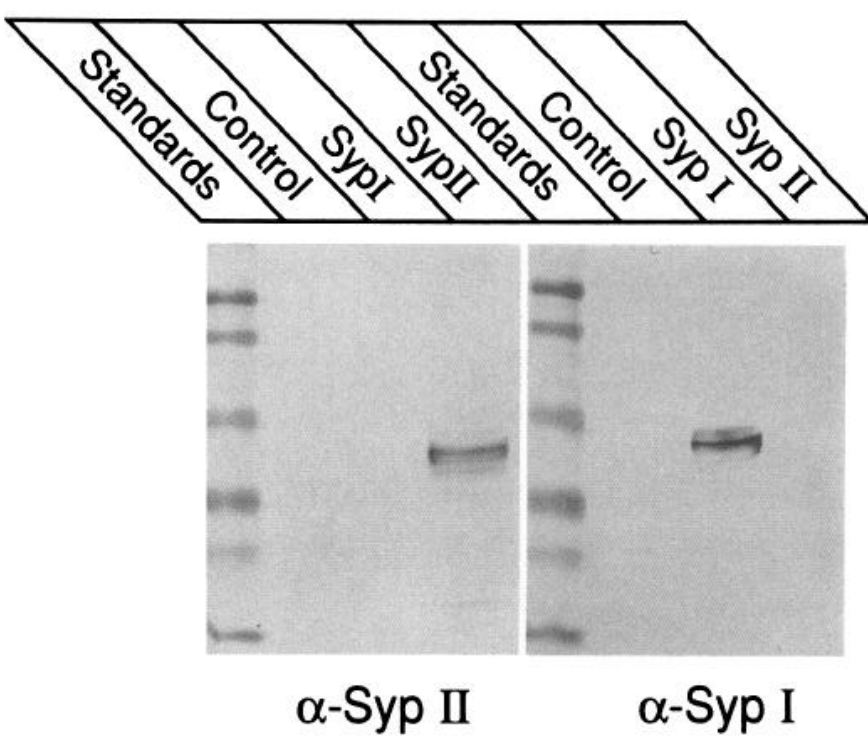

Figure 2. Expression of syp I and syp II in permanently transfected $\mathrm{CHO}$ cell lines and specificity of syp I and syp II antibodies. Nontransfected control CHO cells or cells stably transfected with syp I and syp II expression vectors were analyzed by SDS-PAGE $(7.5 \%$ gels) and immunoblotting using antibodies to syp II (left $)$ and syp I (right). In the left lane of each panel, prestained molecular weight standards (Bio-Rad) were loaded corresponding to the following molecular weights (from top to bottom): $M_{r} 106,000,80,000,49,500,32,500,27,500,18,500$.

transfection into fibroblasts (Johnston et al., 1989b; Cameron et al., 1991; Linstedt and Kelly, 1991a). This targeting is probably due to the tyrosine-rich carboxyl terminus of syp I (Linstedt and Kelly, 1991b). Syp I and syp II are very homologous to each other in the sequences of the transmembrane regions and the sequences connecting the transmembrane regions but share little sequence similarity in their carboxyl-terminal tails (Knaus et al., 1990). We therefore transfected CHO cells with a syp II expression vector to compare its properties in this system with that of syp I.

CHO cell lines expressing syp I or syp II were obtained by transfection and studied by immunoblotting (Fig. 2). The results demonstrate that the two cell lines specifically express the proteins encoded by the expression vectors with which they were transfected. The sizes of syp I and syp II expressed in CHO cells suggest that they are also glycosylated (compare Figs. 1, 2). Furthermore, the immunoblots confirm that the syp I and syp II antibodies are specific for their respective proteins and do not cross-react with each other as would be expected from the divergent sequences of their carboxyl termini.

The relative distributions of syp I and syp II in the transfected cell lines were compared with those of transferrin receptors as a marker for the receptor-mediated endocytosis pathway (Fig. 3). Both proteins had a similar punctate distribution in the transfected cells, which in turn was similar to that of transferrin receptors. We then treated the transfected cells with brefeldin A, a drug that causes the fusion of endosomes and the transGolgi network into an extensive reticular membrane network (Lippincott-Schwartz et al., 1991; Wood et al., 1991). After treatment of the transfected cells with brefeldin A, a coordinate redistribution of syp I and syp II with the transferrin receptor into this network was observed (Fig. 3). Together these results suggest that in transfected $\mathrm{CHO}$ cells syp II is targeted to a similar compartment as syp I and as the transferrin receptor, namely, the receptor-mediated endocytosis pathway. 

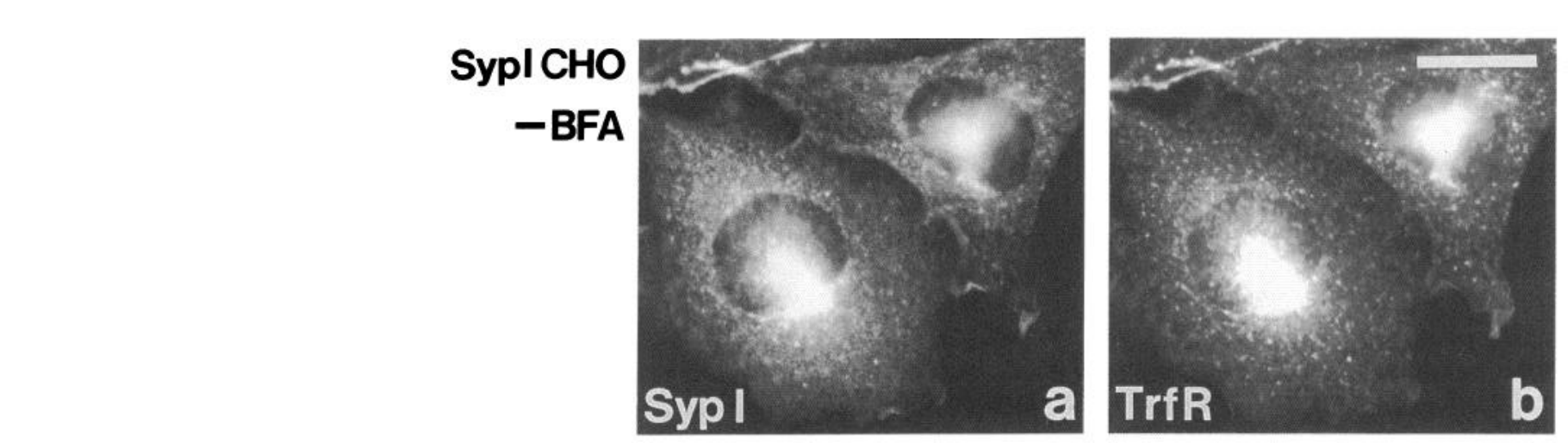

Figure 3. Comparisons of the distributions of transfected syp I and syp II with those of transferrin receptors in $\mathrm{CHO}$ cells. $\mathrm{CHO}$ cells stably expressing syp I $(a-d)$ or syp II $(e-h)$ were double labeled for syp I and II, respectively, and transferrin receptors. Cells were stained either before $(a, b, e$, and $f)$ or
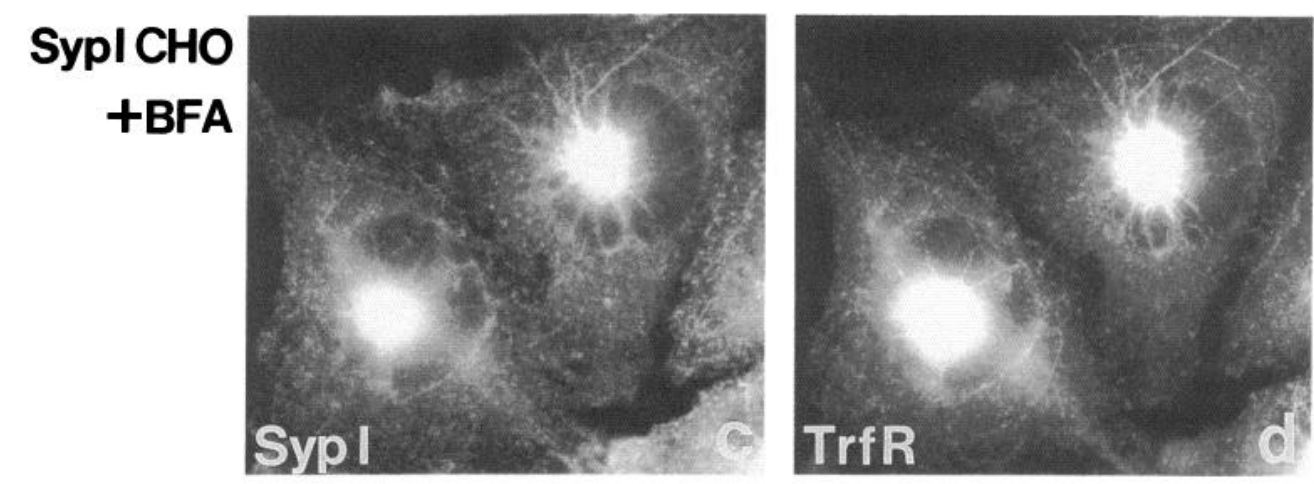

\section{SypllCHO} -BFA after treatment with brefeldin A $(c, d$, $g$, and $h$ ). The punctate distribution of both synaptophysins in untreated cells is very similar to that of the transferrin receptor. Following brefeldin A treatment, both proteins relocalize to the trans-Golgi network-endosomal reticulum that develops after brefeldin A action. Scale bar, $20 \mu \mathrm{m}$.
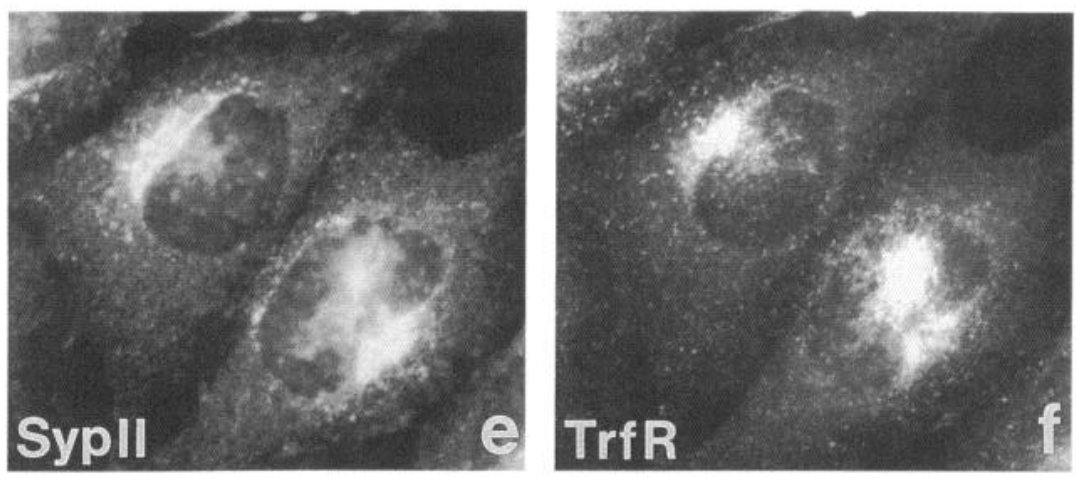

\section{SypllCHO \\ +BFA}
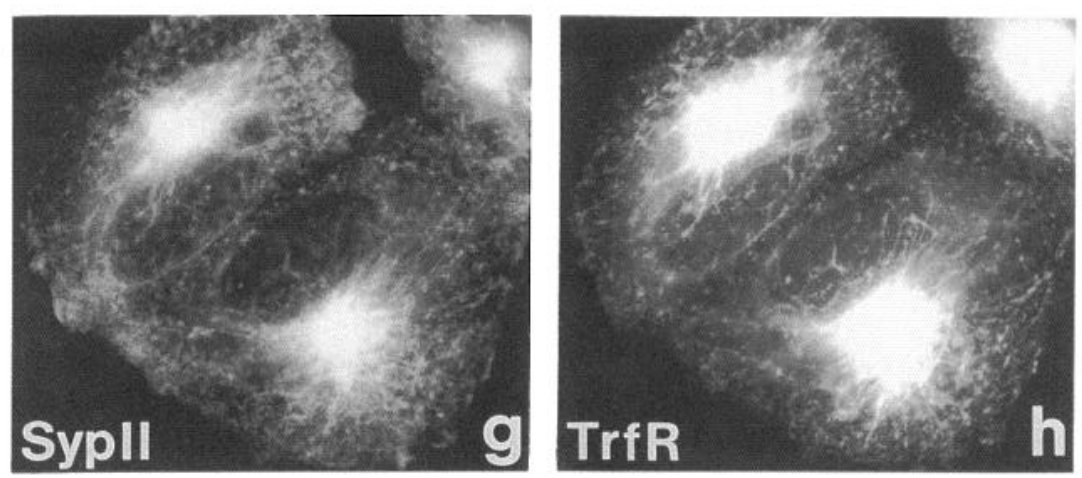

Biochemically, syp I has been shown to be part of a highmolecular-weight complex containing multiple syp I subunits (Rehm et al., 1986; Thomas et al., 1988; Johnston and Südhof, 1990). In addition to syp I subunits, the complex also contains a low-molecular-weight component of an estimated $M_{\mathrm{r}}$ of 18,000 , so it constitutes a heteromultimer (Johnston and Südhof, 1990). There is uncertainty about the number of syp I subunits per complex, with estimates ranging from three subunits (Rehm et al., 1986) to six (Thomas et al., 1988). Syp I contains unstable intramolecular disulfide bonds that can be used to cross-link neighboring subunits in the complex; in addition, subunits can be cross-linked using chemical reagents (Johnston and Südhof, 1990). Because syp II is structurally so similar to syp I, we investigated if syp II also forms high-molecular-weight complexes. Syp I can be efficiently cross-linked by disulfide exchange reactions using $\beta$-mercaptoethanol (Johnston and Südhof, 1990). Although a small degree of cross-linking can also be observed for syp II using this procedure, the degree of cross-linking was 

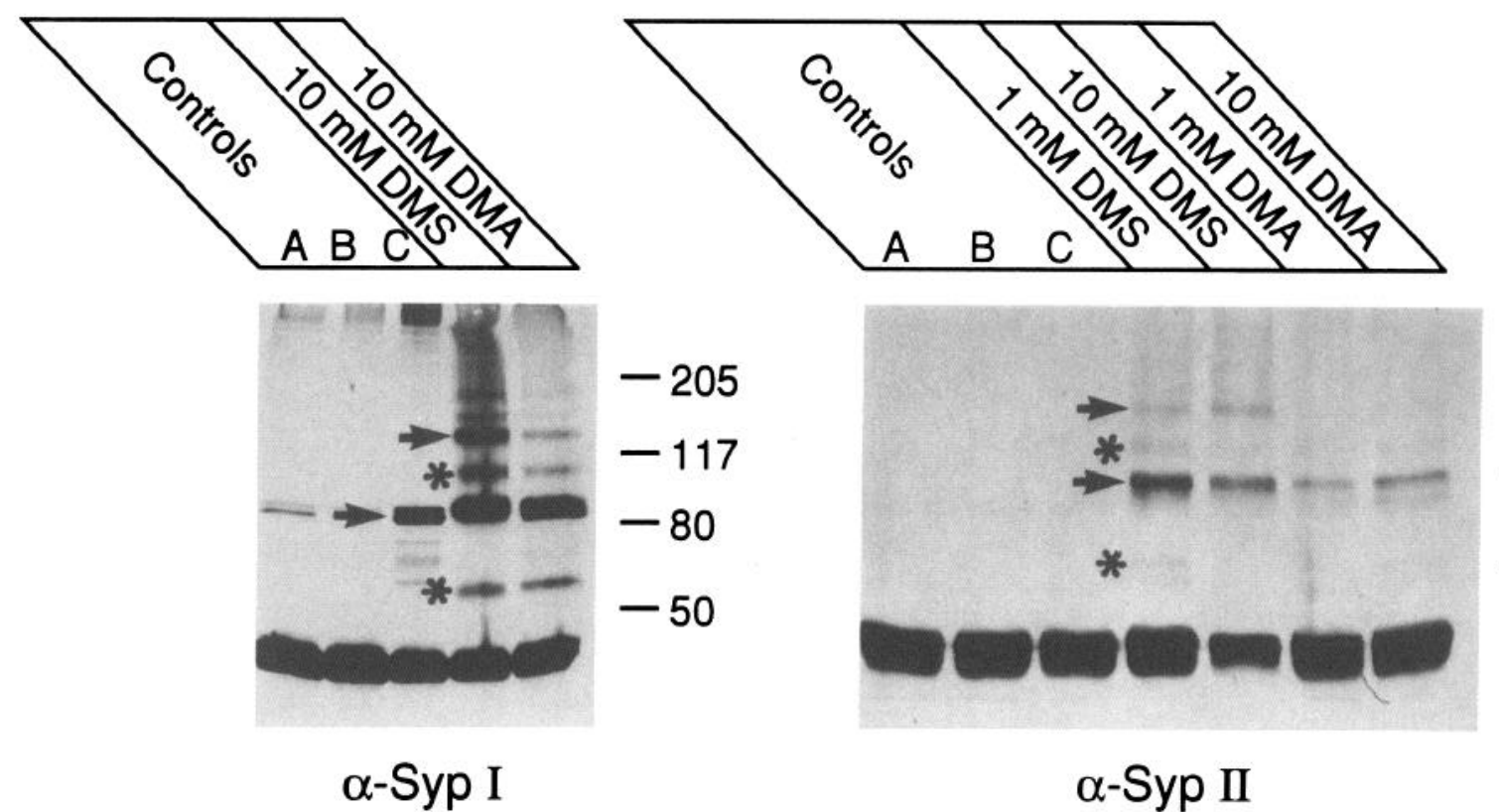

Figure 4. Chemical cross-linking of syp I (left) and syp II (right). Synaptic vesicles were incubated with the indicated concentrations of crosslinking agents ( $D M A$, dimethyl-adipimidate, $D M S$, dimethyl-suberimidate) and analyzed by SDS-PAGE (7.5\% gels) and immunoblotting. Numbers on the right indicate positions of molecular weight markers. Controls included fresh synaptic vesicles analyzed without incubations $(A)$, vesicles incubated on ice $(B)$, and vesicles incubated under the same conditions as used for the cross-linking reactions but in the absence of the cross-linking reagents $(C)$. Putative dimers and trimers of syp I and syp II, respectively, are indicated by arrows on the gels. These putative multimers have sizes corresponding to multiple copies of syp I and II; the additional specifically cross-linked band that is presumably due to cross-linking of syp I and syp II to an unidentified $M_{r} 18,000$ protein is indicated by asterisks.

very low (data not shown). However, syp II could be efficiently cross-linked using two different chemical cross-linking reagents (Fig. 4). Again the efficiency of cross-linking was lower with syp II than with syp I.

For both syp I and syp II, dimers and trimers could be clearly recognized after chemical cross-linking, and tetramers are present for syp I and possibly also for syp II (arrows in Fig. 4). Syp I spontaneously cross-links via disulfide bridges (Johnston and Südhof, 1990), and therefore dimers are already observed in controls in the absence of cross-linking reagents (Fig. 4, left). A specifically cross-linked band of $M_{r} 56,000$ was previously observed upon chemical cross-linking of syp I in synaptic vesicles, suggesting that the syp I complex contains a low-molecularweight subunit in addition to syp I (Johnston and Südhof, 1990). This is also observed with syp II (asterisk in Fig. 4), suggesting that syp II complexes are also heteromultimers. On the whole, these results indicate that syp I and II form very similar supramolecular structures.

The results described above demonstrate that syp I and syp II are similarly glycosylated and oligomerize into similar highmolecular-weight complexes. In addition, upon transfection into fibroblasts, both appear to be targeted to the same subcellular structures. These results are compatible with the hypothesis that syp I and syp II are functionally equivalent, alternatively utilized genes. Previous results using in situ hybridization demonstrated that syp I and syp II are differentially distributed in brain in a pattern, suggesting that either one or the other form of synaptophysin was expressed in a cell (Marqueze-Pouey et al., 1991). The question arises if syp I and syp II are expressed in a mutually exclusive pattern or in a combinatorial pattern, a question that has considerable implications for our thinking about synaptic vesicle protein isoforms. Although the in situ results favored the first hypothesis, this question was not definitively answered. We therefore decided to study the distributions of syp I and syp II in brain by immunocytochemistry.

Light microscopy immunocytochemistry demonstrated a concentration of syp II in nerve terminals as expected for a synaptic vesicle protein. Comparison of the distributions of syp I and II revealed major differences in the localizations of the two proteins. In agreement with previous in situ hybridization data, syp I had a more widespread distribution than syp II, which was highly concentrated in restricted subpopulations of nerve terminals. At the level of sensitivity used in these experiments, we detected no populations of nerve terminals lacking syp I, whereas syp II was undetectable in many regions.

Regions of the hippocampus and cerebral cortex stained by double immunofluorescence for syp I and II are shown in Figure 5. Both syp I and II are present in the large mossy fiber terminals of the CA3 region (Fig. $5 a, b$ ) and the hilus of the hippocampus (Fig. $5 c, d$ ). In these nerve terminals the intensity of syp II immunoreactivity is consistently higher than that of syp I. In the stratum oriens of the CA3 region and the molecular layer of the dentate gyrus, few bright puncta of syp II immunoreactivity stand out on a background of much weaker surrounding syp II immunoreactivity. In contrast, an even, intense syp I immunoreactivity was observed in the latter regions (Fig. $5 a-d$ ). Figure $5, e$ and $f$, shows a field from the cerebral cortex. In this region as well, the even distribution of syp I immunoreactivity contrasts with the more restricted and heterogeneous syp II immunoreactivity.

In the cerebellum syp II had an unusual and peculiar distribution, as shown at low power in Figure 6. The concentration of syp II but not syp I in the molecular layer of the cerebellar cortex displayed a rostrocaudal gradient. As demonstrated in 
Figure 5. Relative distributions of syp I and syp II in the hippocampus and cortex of rat brain as assessed by immunofluorescence staining. Rat brain frozen sections were double labeled by a monoclonal antibody to syp I ( $a, c$, and $e$ ) and a polyclonal antibody to syp II $(b, d$, and $f) . a$ and $b$ show the CA 3 region of the hippocampus. Bright puncta of immunoreactivity visible in the top portion of the figure ( $S R$, stratum radiatum) correspond to large mossy fiber terminals that are positive for both proteins but are more intensely reactive for syp II. In the stratum oriens $(S O)$, syp I immunoreactivity is more intense than syp II reactivity $(S P$, stratum pyramidale). $c$ and $d$ depict a detail of the dentate gyrus with a portion of the molecular layer $(M L ; G C$, granule cell layer; $H$, hilus). Syp II immunoreactivity is very high in synapses of the hilus but only low in the other two layers. $e$ and $f$ show cerebral cortex. Note the difference between the homogeneous punctate distribution of syp I immunoreactivity and the heterogeneous distribution of syp II immunoreactivity, which is concentrated only in a subpopulation of nerve terminals. Scale bar, $20 \mu \mathrm{m}$.
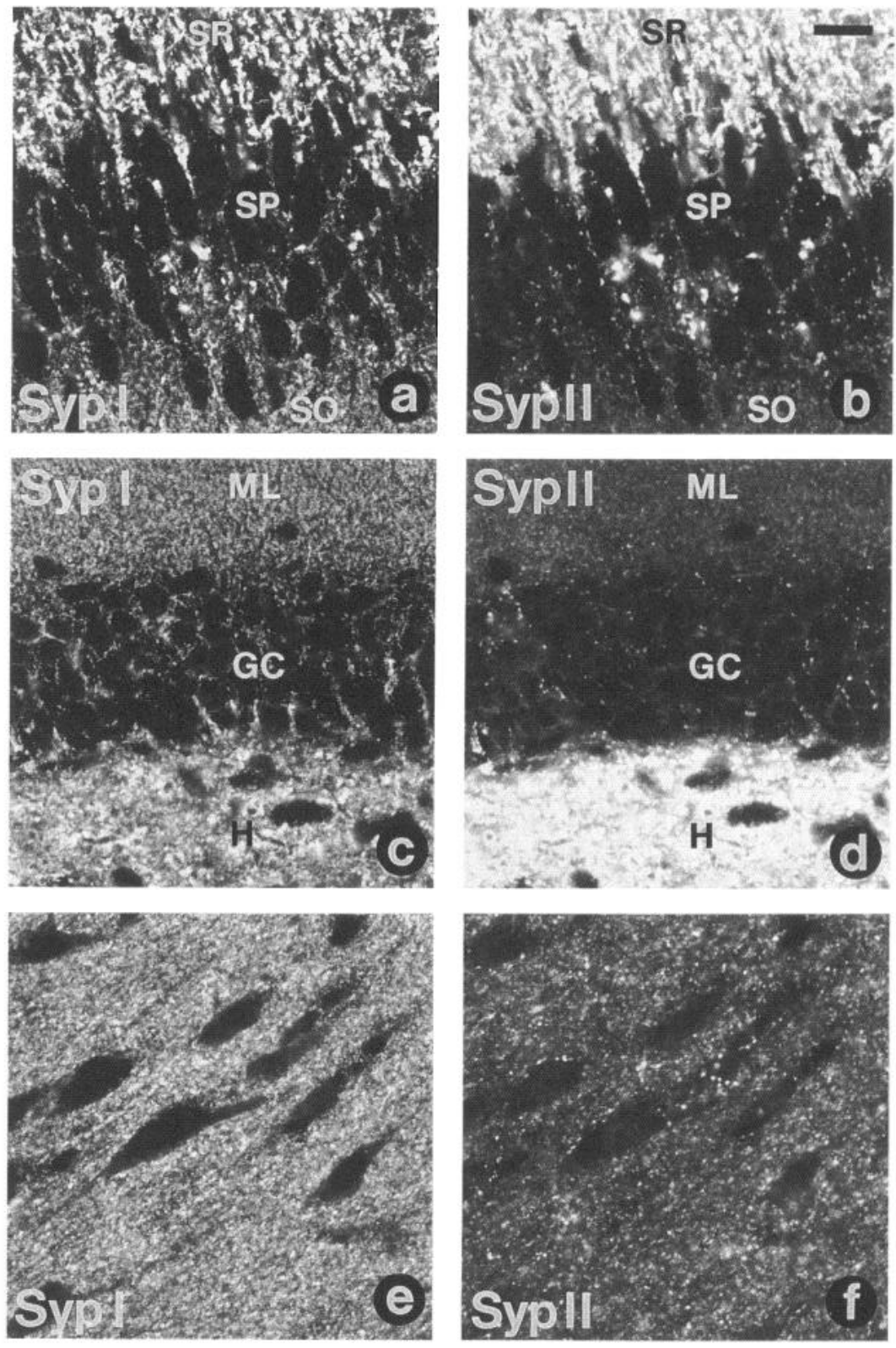

Figure $6, b$ and $d$, syp II immunoreactivity was present throughout the molecular layer of the most caudal folium but only in the most superficial region of the molecular layer in the most rostral folium. In the most caudal folium, staining intensity was higher than the staining intensity for syp I. A progressive change from one pattern to the other could be observed in a caudorostral direction. In the same cerebellar section, syp I immunoreactivity had an even distribution throughout the molecular layer of the entire cerebellar cortex (Fig. 6a,c).

The differential distribution of syp I and II immunoreactivities in different regions of the cerebellar cortex is further illustrated in the pairs of figures shown in Figure 7. Sagittal sections of a caudal and a rostral region of the cerebellar cortex are shown in Figure 7, $a$ and $b$, and $c$ and $d$, respectively. The similar distributions of syp I and II observed in the molecular layer of caudal regions (Fig. 7a,b) suggest a colocalization of both proteins in most nerve terminals, including parallel fiber terminals. In the rostral region shown in Figure $7, c$ and $d$, syp II is primarily found in varicose axons that have the morphological characteristics of climbing fibers. Some of the varicosities appear to be more intensively immunoreactive for syp II than for syp I. A higher magnification of one of these regions to illustrate this finding is shown in Figure 7, $g$ and $h$. A coronal view of the superficial regions of the molecular layer in the rostral third of the cerebellum is shown in Figure 7, $e$ and $f$. In the field stained for syp II (Fig. $7 f$ ) one can identify, in addition to the climbing fibers, some fibers that run in the coronal plane in the most superficial regions under pial surface. These are probably syp II-positive parallel fibers.

In all regions of the cerebellar cortex, very little syp II immunoreactivity is detectable in the granular layer, where only scattered glomeruli are intensely positive (Figs. $6,7 b, d$ ). In the deep cerebellar nuclei, syp II immunoreactivity is visible only in a few nerve terminals (Fig. $7 i, j$ ).

To determine the subcellular localization of syp II within nerve terminals, an immunogold procedure similar to the one 

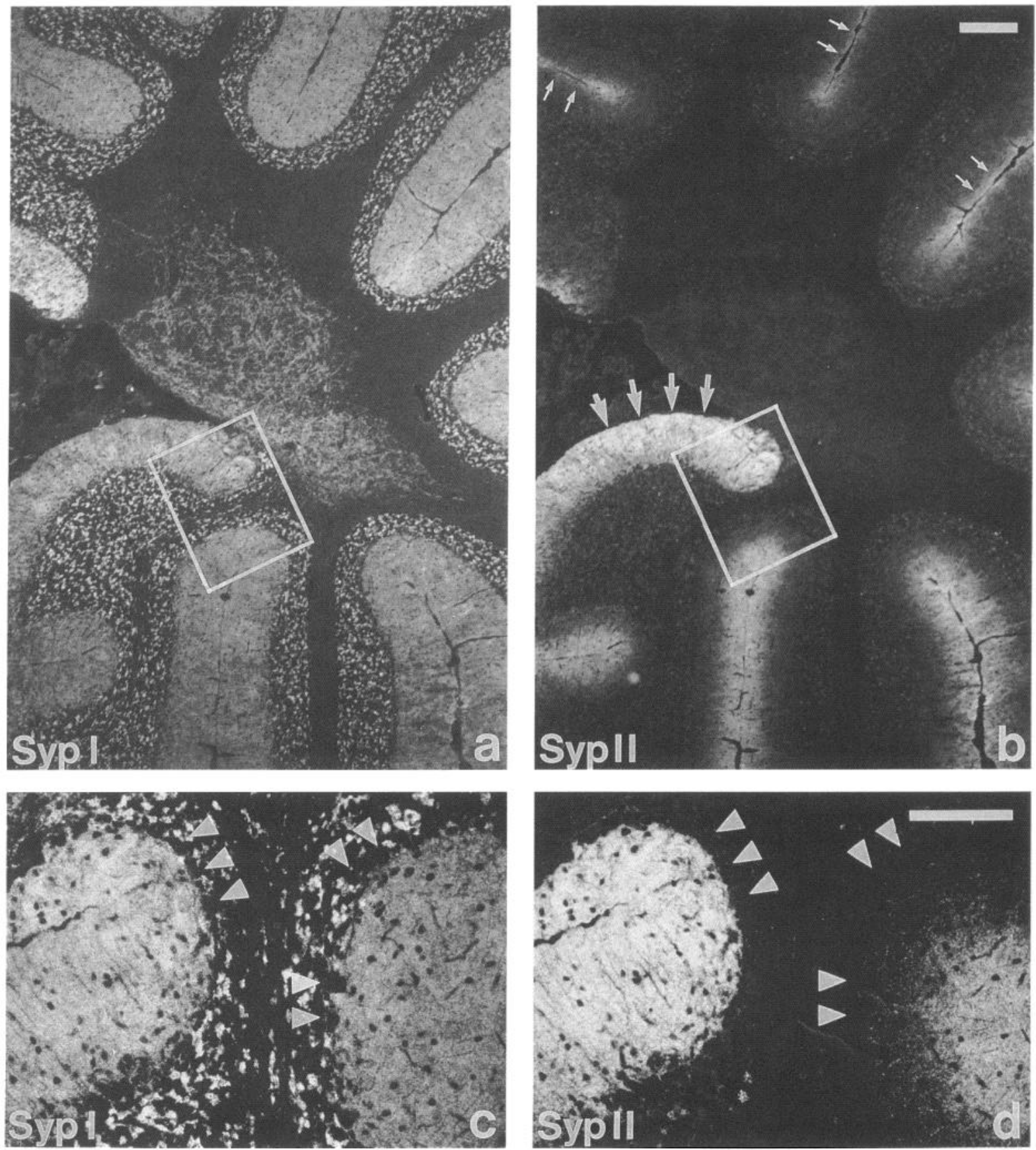

Figure 6. Comparison of the distributions of syp I and syp II in sagittal sections of the cerebellar cortex by double immunofluorescence labeling. $a$ and $b$ show an overview; the rostral-caudal axis corresponds to a clockwise arrangement of the folia. Syp I is widely distributed in all regions containing synapses. Syp II immunoreactivity is largely restricted to the molecular layer of the cortex, where it exhibits a caudorostral (counterclockwise in the figure) gradient. Syp II is highly concentrated throughout the molecular layer of the caudal portion of the most caudal lobule (large arrows) but becomes progressively restricted to the superficial layers as one moves rostrally along the cerebellar surface. In the rostral folia immunoreactivity is concentrated only under pial surface (small arrows). The regions enclosed by rectangles in $a$ and $b$ are shown at a higher magnification in $c$ and $d$. Arrowheads indicate positions of Purkinje cells in the two adjacent folia shown. Note also the difference between syp I and syp II in the staining pattern of the granule layer. Only very few glomeruli are intensely positive for syp II, whereas all are labeled by syp I. Scale bars: $a$ and $b, 0.2 \mathrm{~mm} ; c$ and $d, 0.1 \mathrm{~mm}$.

previously used for the localization of syp I was employed (Navone et al., 1986). This procedure involves immunogold labeling of cellular fragments of brain tissue prior to Epon embedding. As shown in Figure 8, syp II was found to be concentrated around synaptic vesicles in presynaptic nerve terminals using this technique. In some cases, a given synaptic vesicle was decorated by several gold particles (enclosed by a circle in Fig. $8 a$ ).
The variability of labeling around individual vesicles is probably due to uneven accessibility of synaptic vesicle surfaces to antibodies. As previously shown for syp I (Navone et al., 1986), a few larger membrane profiles that are positive for syp II may represent endosomal structures (Fig. 8c).

The immunocytochemical results demonstrate colocalization of syp I and syp II in nerve terminals. This raises the question 

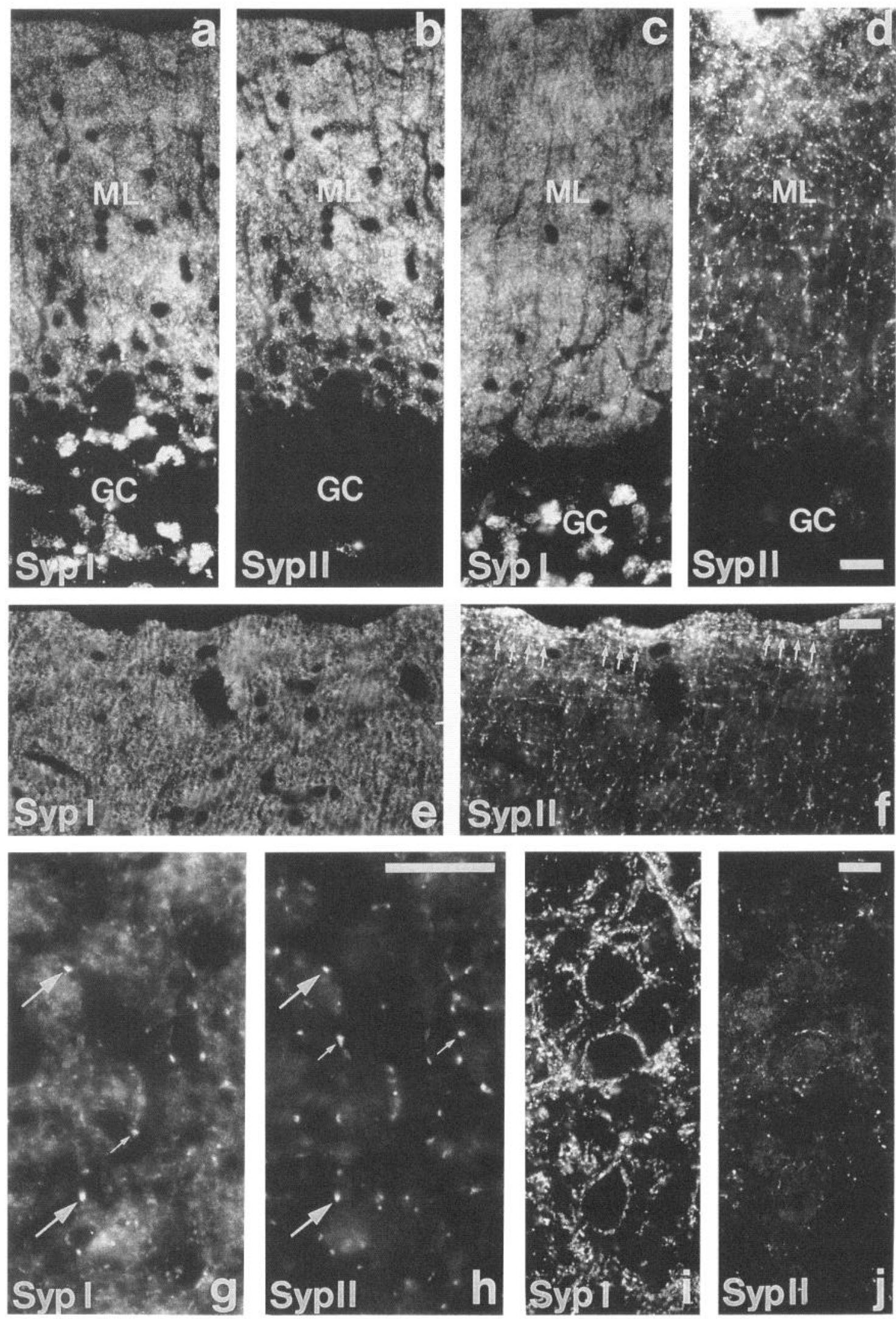

Figure 7. Localization of syp I and syp II in rat cerebellum. $a-d$ show sagittal sections of a caudal $(a$ and $b)$ and rostral $(c$ and $d)$ cerebellar folium. Immunoreactivity for syp II is very similar to that of syp I in the molecular layer $(M L)$ of the caudal folium but substantially different in the molecular layer of the rostral folium. In the rostral section $(c$ and $d)$, syp II immunoreactivity is largely confined to varicose fibers with features of climbing fibers and to synapses located in the most superficial layers. Little syp II immunoreactivity is present in the granule cell layer ( $G C)$. $e$ and $f$ show a coronal section of a rostral folium. In contrast to the homogeneous distribution of syp I, syp II is primarily localized in climbing fibers and in some parallel fibers in the superficial portion of the layer (arrows). $g$ and $h$ depict a higher magnification of a field similar to that shown in $e$ and $f$. Large arrows point to nerve terminals positive for both synaptophysins, and small arrows, to nerve terminals positive for either one or the other of the two synaptophysin isoforms. $i$ and $j$ show double labeling of the deep cerebellar nuclei, demonstrating virtual absence of syp II in the presence of strong syp I immunoreactivity. Scale bars, $20 \mu \mathrm{m}$. 

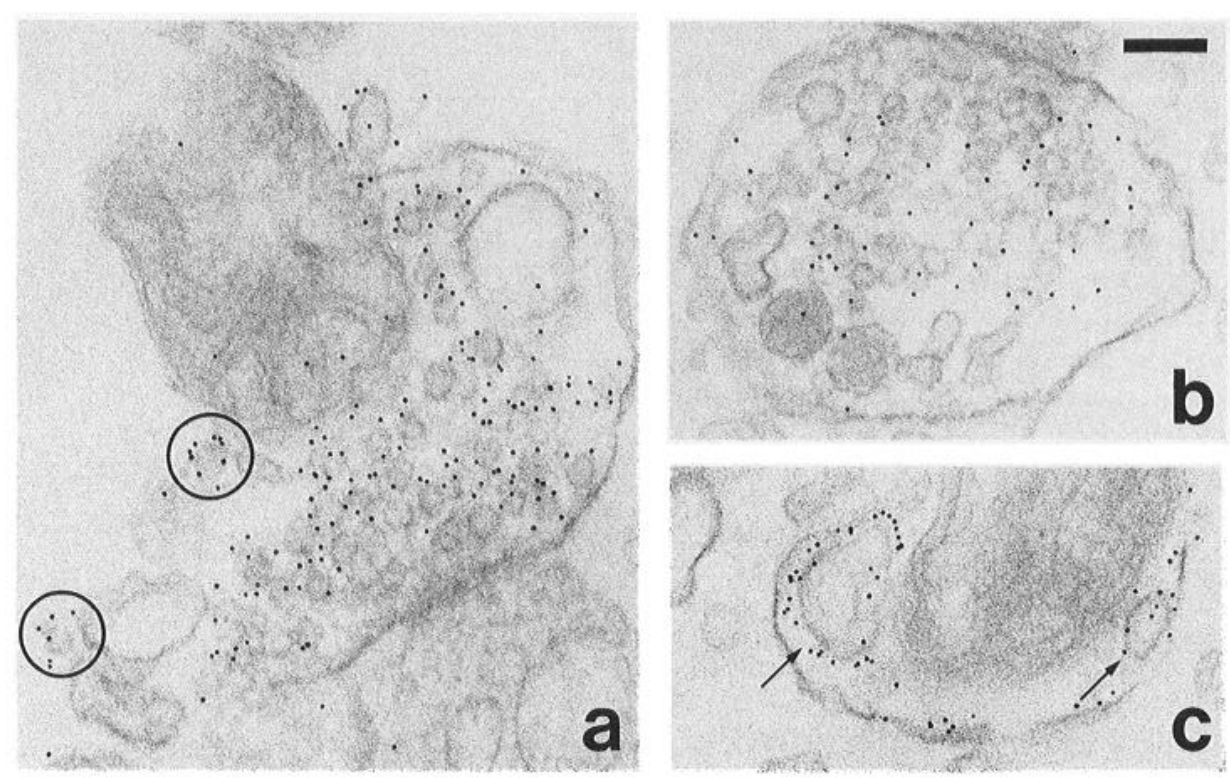

Figure 8. Subcellular localization of syp II in nerve terminals by immunogold electron microscopy. The micrographs show rat brain nerve terminals embedded in agarose and labeled for syp II. In $a$ and $b$, gold particles are concentrated in regions of nerve terminals enriched in synaptic vesicles and around isolated synaptic vesicles ( $\mathrm{cir}$ cles). $c$ demonstrates gold particles around larger membranous structures with irregular profiles (arrows), most likely endosomes. Scale bar, $0.1 \mu \mathrm{m}$. if syp I and syp II are on the same synaptic vesicle or if they are on separate vesicles in the same nerve terminal. To address this question, synaptic vesicles were immunoprecipitated from the low-speed supernatants of rat brain homogenates using monoclonal antibodies coupled to plastic beads (Burger et al., 1989). The immunoprecipitate was then immunoblotted for syp I and syp II. As shown in Figure 9, most syp II could be coimmunoprecipitated with syp I using this procedure. Less than $10 \%$ of the total protein was immunoprecipitated with this procedure, and immunoblots for proteins not found on synaptic vesicles demonstrated that they were not immunoprecipitated (data not shown). Together these results suggest that syp I and syp II are not only in the same nerve terminal but also on the same synaptic vesicles.

We have shown above that syp I and II are part of multimeric complexes that were thought to contain multiple copies of syp I or syp II because the cross-linked complexes appear to be integral sums of single subunits (Fig. 4). However, if syp I and II are on the same vesicles, the question arises of whether they form heteromultimers and could be complexed with each other. To address this point, proteins in rat brain synaptosomes were solubilized with Triton X-100, and syp I and syp II were immunoprecipitated from the solubilized proteins with specific antibodies. The possible association of syp I and syp II with each other was then tested by immunoblotting the immunoprecipitates both with the antibody used for the immunoprecipitation as a positive control, as well as with the antibody to the other synaptophysin to determine if it was coimmunoprecipitated. In addition, these experiments were performed with control immunoprecipitations with antibodies to clathrin light chain that should not immunoprecipitate either syp I or syp II. The results clearly demonstrate that syp I antibodies do not immunoprecipitate syp II, and syp II antibodies do not immunoprecipitate syp I, and that control antibodies do not immunoprecipitate either syp I or syp II (Fig. 10). As a consequence, we conclude that syp I and syp II form separate but similar multimeric complexes on the same synaptic vesicles.

\section{Discussion}

Many synaptic vesicle proteins are present in multiple isoforms. The functional relevance of multiple isoforms and their relative biochemical properties is not known for any synaptic vesicle protein. It is possible to postulate at least two hypotheses. (1) Synaptic vesicle protein isoforms may be isofunctional and expressed in alternative neuronal pathways (the alternative pathway hypothesis). A population of neurons would express only one or the other of the two isoforms, which have slightly different properties but have essentially the same functions. (2) Synaptic vesicle protein isoforms, although similar, may contain functional specialization with respect to each other (the functional specialization hypothesis). This would imply a spectrum of ex-
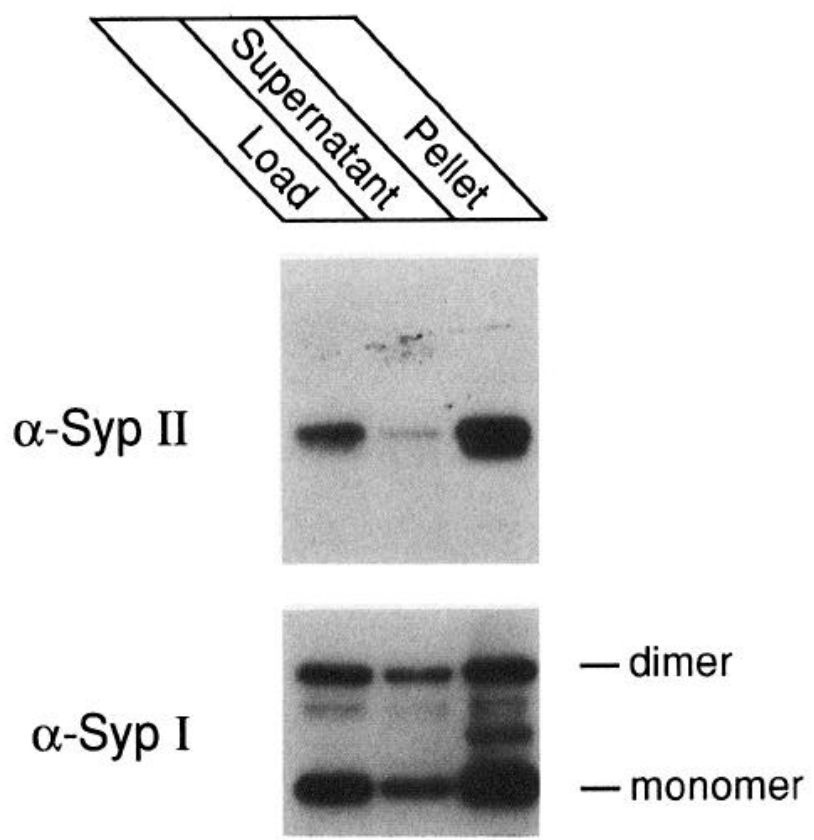

Figure 9. Coimmunoprecipitation of syp II with syp I-containing synaptic vesicles. Synaptic vesicles were immunoprecipitated from rat brain postnuclear supernatant (Load, left lane) using monoclonal antibodies to syp I coupled to beads. Aliquots of the resulting postimmunoprecipitation supernatant (middle lane) and the synaptic vesicle pellet (right lane) were analyzed by SDS-PAGE ( $10 \%$ gels) and immunoblotting using ${ }^{125}$ I-labeled protein A for detection. Spontaneously formed syp I dimers are visible on the syp I blot in addition to traces of IgG heavy chain, whereas syp II does not form dimers as readily. 

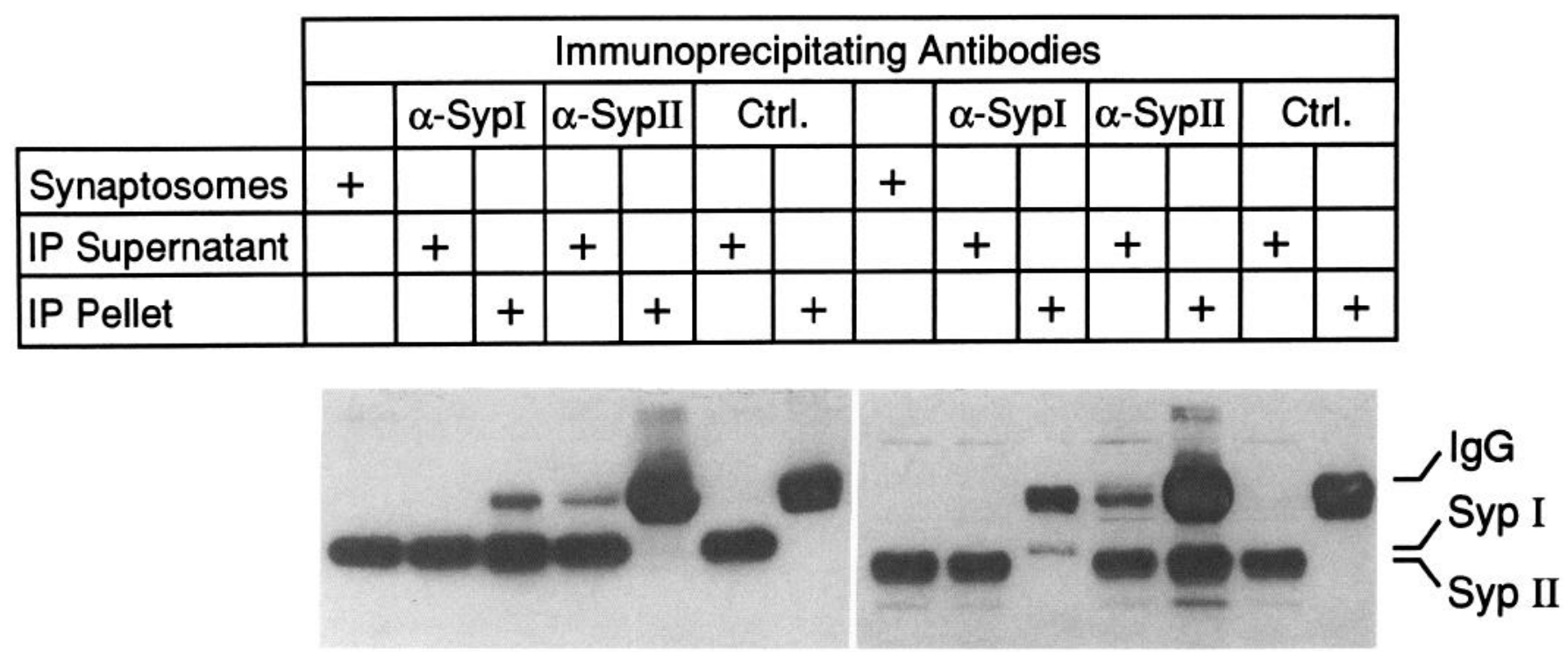

\begin{tabular}{|c|c|}
\hline$\alpha$-Syp I & $\alpha$-Syp II \\
\hline \multicolumn{2}{|c|}{ Immunoblotting Antibodies } \\
\hline
\end{tabular}

Figure 10. Immunoprecipitation of syp I and syp II from solubilized synaptosomes. Synaptosomal proteins solubilized in Triton X-100 were subjected to immunoprecipitations with antibodies to syp I and syp II, and to clathrin light chains as a negative control. Immunoprecipitates were then analyzed by SDS-PAGE on $10 \%$ gels followed by immunoblotting with antibodies to either syp I (left) or syp II (right). In each panel, the starting synaptosomal protein extract is loaded on the left lane followed by the supernatants and pellets of the immunoprecipitations with the three different antibodies as indicated. The upper band above the syp I and syp II bands corresponds to IgG heavy chain from the immunoprecipitations. Immunoreactive bands were visualized with immunoperoxidase-labeled secondary antibodies followed by enhanced chemiluminescence.

pression ranging from coexpression of multiple forms to the expression of a single form. This is the pattern that was observed previously for synapsins, demonstrating that the four synapsins are expressed in a combinatorial manner ranging from the expression of a single synapsin to multiple synapsins in a given nerve terminal (Südhof et al., 1989).

In the present study, we have attempted to address this question for the synaptophysins that exhibit two isoforms, syp I and syp II. We first compared the biochemical properties of the two proteins. Our results demonstrate that two salient characteristics of syp I can also be found in syp II. First, both syp I and syp II appear to form heteromultimeric high-molecular-weight complexes that consist of several subunits of syp I or II complexed to a low-molecular-weight component. Second, both syp I and syp II seem to be targeted to the receptor-mediated endocytosis pathway after transfection into fibroblastic $\mathrm{CHO}$ cells. These results provide further evidence for the previously postulated relation of the synaptic vesicle pathway to the receptor-mediated endocytosis pathway (Johnston et al., 1989b; Cameron et al., 1991).

We next investigated the relative distributions of syp I and II in rat brain. Their expression was not mutually exclusive but combinatorial. Syp I was present in most if not all nerve terminals, whereas syp II had a more restricted distribution and seemed to be almost always coexpressed with syp I. A few syp II-positive nerve terminals had very low to almost undetectable levels of syp I, suggesting that there may be rare nerve terminals that do not express syp I.

An unanticipated finding was that syp II was expressed in a rostrocaudal gradient in cerebellar cortex. Several antigens have previously been shown to be distributed in the cerebellum in striking patterns in spite of the homogeneity of the cerebellar cytoarchitecture throughout the cerebellum (e.g., see Leclerc et al., 1992). However, to our knowledge no rostrocaudal gradient has previously been observed, and no graded expression of a synaptic vesicle protein is known for any region of the brain. If syp II expression confers special characteristics onto its resident synapses, the gradient of expression in the molecular layer would imply a gradient in the synaptic properties in the molecular layer. Such a gradient would be well suited to participate in positional information.

The coexpression of syp I and syp II raises the question of whether they are colocalized on the same synaptic vesicles, and if so, whether they form multimeric complexes with each other. Immunoelectron microscopy demonstrated that syp II is localized to synaptic vesicles (Fig. 8), confirming that it is a synaptic vesicle protein (Knaus et al., 1990). Immunoprecipitations of synaptic vesicles with antibodies to syp I resulted in the coprecipitation of most of the syp II together with syp I, suggesting that most if not all vesicles containing syp II also contain syp I (Fig. 9). However, after detergent solubilization, neither syp I nor syp II antibodies were able to immunoprecipitate each other, demonstrating that they are not complexed to each other (Fig. 10). Together these results show that syp I and syp II are both synaptic vesicle proteins that are largely colocalized on the same vesicles. Each of them is part of a high-molecular-weight complex containing several synaptophysin subunits in addition to other components, but they are not part of the same complex. 
What implications can be drawn from these findings for the functional relevance of multiple synaptic vesicle protein isoforms in general, and for the presence of two synaptophysins in particular? It is clear that syp I and II are not simply alternative isofunctional proteins; instead, syp I seems to be the generally used form that is complemented or superseded by syp II in selected nerve terminals. This raises the hypothesis that syp II may confer specific additional characteristics on selected synapses. It will be interesting to determine if similar distributions can also be observed for other synaptic vesicle protein isoforms that were shown by RNA data to be differentially distributed in brain (Trimble et al., 1990; Geppert et al., 1991; Wendland et al., 1991).

Our results give further insights into the synaptophysin complex. The fact that both syp I and syp II form similar highmolecular-weight complexes on the same vesicle but do not complex with each other suggests a very selective mechanism of assembly. Other synaptic vesicle proteins are probably also members of high-molecular-weight complexes, such as synaptotagmin (Perin et al., 1991; Brose et al., 1992), and it will be interesting to see what the isoform specificity of their assembly will be.

\section{References}

Archer BT, Ozcelik T, Jahn R, Francke U, Südhof TC (1990) Structures and chromosomal localizations of two human genes encoding synaptobrevins 1 and 2 . J Biol Chem 265:17267-17273.

Bixby JL (1992) Identification of an alternatively spliced avian member of the synaptophysin gene family. Mol Brain Res 13:339-348.

Brose N, Petrenko AG, Südhof TC, Jahn R (1992) Synaptotagmin: a $\mathrm{Ca}^{++}$sensor on the synaptic vesicle surface. Science 256:1021-1025.

Burger P, Hell J, Mehl E, Krasel C, Lottspeich F, Jahn R (1989) GABA and glycine in synaptic vesicles: storage and transport characteristics. Neuron 7:287-293.

Cameron PL, Südhof TC, Jahn R, De Camilli P (1991) Colocalization of synaptophysin with transferrin receptors: implications for synaptic vesicle biogenesis. J Cell Biol 115:151-164.

De Camilli P, Harris SM, Huttner WB, Greengard P (1983) Synapsin I (protein I), a nerve terminal-specific phosphoprotein: II. Its specific association with synaptic vesicles demonstrated by immunocytochemistry in agarose-embedded synaptosomes. J Cell Biol 96:13551373.

Elferink LA, Trimble WS, Sheller RH (1989) The synaptic vesicle protein SV2 is a novel type of transmembrane transporter. Cell 70: 861-867.

Fischer von Mollard G, Mignery GA, Baumert M, Burger PR, Perin M, Jahn R, Südhof TC (1990) Rab3 is a small GTP-binding protein exclusively localized to synaptic vesicles. Proc Natl Acad Sci USA 87:1988-1992.

Geppert M, Archer BT III, Südhof TC (1991) Synaptotagmin II: a novel differentially distributed form of synaptotagmin. J Biol Chem 266:13548-13552.

Jahn R, Schiebler W, Ouimet C, Greengard P (1985) A 38,000 dalton membrane protein (p38) present in synaptic vesicles. Proc Natl Acad Sci USA 82:4137-4141.

Jahn R, Navone F, Greengard P, De Camilli P (1987) Biochemical and immunocytochemical characterization of $\mathrm{p} 38$, an integral membrane glycoprotein of small synaptic vesicles. Ann NY Acad Sci 493: $497-499$.

Johnston PA, Südhof TC (1990) The multisubunit structure of synaptophysin. Relationship between disulfide bonding and homo-oligomerization. J Biol Chem 265:8869-8873.

Johnston PA, Jahn R, Südhof TC (1989a) Transmembrane topography and evolutionary conservation of synaptophysin. J Biol Chem 264:1268-1273.

Johnston PA, Cameron PL, Stukenbrok H, Jahn R, De Camilli P, Süd- hof TC $(1989 \mathrm{~b})$ Synaptophysin is targeted to similar microvesicles in CHO- and PC12-cells. EMBO J 8:2863-2872.

Knaus P, Marqueze-Pouey B, Scherer H, Betz H (1990) Synaptoporin, a novel putative channel protein of synaptic vesicles. Neuron 5:453462.

Laemmli UK (1970) Cleavage of structural proteins during the assembly of the head of bacteriophage T4. Nature 331:680-685.

Leclerc N, Schwarting GA, Herrup K, Hawkes R, Yamamoto M (1992) Compartmentation in mammalian cerebellum: zebrin II and P-path antibodies define three classes of sagittally organized bands of Purkinje cells. Proc Natl Acad Sci USA 89:5006-5010.

Leube RE, Wiedenmann B, Granke WW (1989) Topogenesis and sorting of synaptophysin: synthesis of a synaptic vesicle protein from a gene transfected into non-neuroendocrine cells. Cell 59:433-446.

Linstedt AD, Kelly RB (1991a) Synaptophysin is sorted from endocytotic markets in neuroendocrine $\mathrm{PC} 12$ cells but not transfected fibroblasts. Neuron 7:309-317.

Linstedt AD, Kelly RB (1991b) Endocytosis of the synaptic vesicle protein, synaptophysin, requires the $\mathrm{COOH}$-terminal tail. J Physiol (Paris) 85:90-96.

Lippincott-Schwartz J, Yuan L, Tipper C, Amherdt M, Orci L, Klausner RD (1991) Brefeldin A's effect on endosomes, lysosomes, and TGN suggests a general mechanism for regulating organelle structure and membrane traffic. Cell 67:601-616.

Marqueze-Pouey B, Wisden W, Malosio ML, Betz H (1991) Differential expression of synaptophysin and synaptoporin mRNAs in the postnatal rat central nervous system. J Neurosci 1 1:3388-3397.

Matsui Y, Kikuchi A, Kondo J, Hishida T, Teranishi Y, Takai Y (1988) Nucleotide and deduced amino acid sequences of a GTP-binding protein family with molecular weights of 25,000 from bovine brain. J Biol Chem 263:1 1071-11074.

Matteoli M, Takei K, Cameron R, Hurlbut P, Johnston PA, Südhof TC, Jahn R, De Camilli P (1991) Association of Rab3 with synaptic vesicles at late stages of the secretory pathway. J Cell Biol 115:625633.

Navone F, Jahn R, Di Gioia G, Stukenbrok H, Greengard P, De Camilli $P$ (1986) Protein p38: an integral membrane protein specific of small clear vesicles of neurons and neuroendocrine cells. J Cell Biol 255 : 2675-2681.

Perin MS, Brose N, Jahn R, Südhof TC (1991) Domain structure of synaptotagmin (p65). J Biol Chem 266:623-629.

Rehm H, Wiedenmann B, Betz H (1986) Molecular characterization of synaptophysin, a major calcium-binding protein of the synaptic vesicle membrane. EMBO J 5:535-541.

Südhof TC, Jahn R (1991) Proteins of synaptic vesicles involved in exocytosis and membrane recycling. Neuron 6:665-677.

Südhof TC, Lottspeich F, Greengard P, Mehl E, Jahn R (1987) Synaptophysin: a synaptic vesicle protein with four transmembrane regions and a novel cytoplasmic domain. Science 238:1142-1144.

Südhof TC, Czernik AJ, Kao H, Takei K, Johnston PA, Horiuchi A, Wagner M, Kanazir SD, Perin MS, De Camilli P, Greengard P (1989) Synapsins: mosaics of shared and individual domains in a family of synaptic vesicle phosphoproteins. Science 245:1474-1480.

Takei K, Stukenbrok H, Metcalf A, Mignery G, Südhof T, Volpe P, De Camilli $P$ (1992) Association of Rab3 with synaptic vesicles at late stages of the secretory pathway. J Cell Biol 115:625-633.

Thomas L, Hartung K, Langosch D, Rehm H, Bamber E, Franke WW, Betz $H$ (1988) Identification of synaptophysin as a hexameric channel protein of the synaptic vesicle membrane. Science 242:1050-1053.

Trimble WS, Gray TS, Elferink LA, Wilson MC, Scheller RII (1990) Distinct patterns of expression of two VAMP genes within the rat brain. J Neurosci 10:1380-1387.

Wendland B, Miller KG, Schilling J, Scheller RH (1991) Differential expression of the p65 gene family. Neuron 6:993-1007.

Wiedenmann B, Franke WW (1985) Identification and localization of synaptophysin, an integral membrane glycoprotein of $M_{r} 38,000$ characteristic of presynaptic vesicles. Cell 41:1017-1028.

Wood SE, Park JE, Brown WJ (1991) Brefeldin A causes a microtubule-mediated fusion of the TGN and early endosome. Cell 67:591600.

Zahraoui A, Touchot N, Chardin P, Tavitian A (1989) The human rab genes encode a family of GTP-binding proteins related to yeast YPT1 and SEC4 products involved in secretion. J Biol Chem 264: 12394-12401. 